ISSN: 0213-2079 - ISSN electrónico: 2386-3889

DOI: https://doi.org/10.14201/shhmo2019412123153

\title{
SIN LEÓN NO HUBIERA ESPAÑA. HISTORIA, RELIGIÓN Y PROPAGANDA EN UNA CIUDAD DE LA EDAD MODERNA
}

Without Leon, Spain would never have existed. History,
religion and propaganda in an Early Modern city

Alfredo MARTÍN GARCÍA

Universidad de León

Orcid: 0123-1531-6906-0210

Fecha de envío: 15 de octubre de 2019

Fecha de aceptación: 19 de noviembre de 2019

RESUMEN: Se analiza, a través de la producción impresa de los siglos XVI, XVII y XVIII, la estrategia premeditada de los poderes políticos y religiosos de la ciudad de León por difundir una visión idealizada de su pasado, en el contexto del desarrollo de las historias locales en la España de aquella época. En el campo religioso se buscaba defender la antigüedad de la Iglesia legionense, retrotrayéndola a los primitivos tiempos de las persecuciones romanas. En lo político, se buscaba asentar la idea de León como origen de la monarquía católica, convirtiendo a los reyes leoneses medievales en los responsables de las futuras glorias de la Corona. Aquellas reivindicaciones no sólo contaban con el altavoz de la imprenta, sino que tenían su prolongación en las festividades religiosas y civiles que se desarrollaban a lo largo del año.

Palabras clave: Edad Moderna; León; imprenta; historia local; Iglesia.

ABSTRACT: The aim of this study was to analyse print production in the 16th, 17th and 18th centuries in order to elucidate an intentional 
strategy on the part of the political and religious authorities in the city of León aimed at disseminating an idealised vision of its past, in the context of the development of local history in Early Modern Spain. The religious authorities sought to vindicate the antiquity of the Church in León by portraying it in the distant times of Roman persecution. Meanwhile, the political authorities aimed to consolidate the idea of León as the origin of the Catholic Monarchy, depicting the mediaeval León monarchs as responsible for the future glories of the Crown. These images were propagated not only through the medium of print, but also through the annual calendar of religious and civic holidays.

Keywords: Early Modern Period; León; printing press; local history; church.

\title{
LEÓN Y LA AÑORANZA DE LAS GLORIAS DEL PASADO ${ }^{1}$
}

\author{
En argén León contemplo, \\ fuerte, purpureo, triunfal, \\ de veinte santos exemplo \\ donde está el único templo \\ real y sacerdotal. \\ Tuvo veinte y quatro reyes, \\ Antes que Castilla leyes, \\ hizo el fuero sin querellas, \\ libertó las cien doncellas \\ de las infernales greyes.
}

Esta octava real, que según señalaba el marqués de Fuentehoyuelo, lucía en la cornisa de la sala principal de los palacios municipales de León en el siglo XVII (Cabeza de Vaca, 1693:2), refleja los principales hitos de la historia de la ciudad - mezcla de realidad y ficción - cuya memoria sus elites trataron de difundir durante los Tiempos Modernos, tanto a través del patrocinio de diferentes obras históricas o literarias como mediante la celebración de determinadas festividades públicas (Viforcos, 1992: 57-60; Campos y Viforcos, 1995: 121). Los dos objetivos básicos y complementarios de este esfuerzo propagandístico eran reivindicar a la ciudad como cuna de la monarquía española y subrayar la antigüedad de su Iglesia,

1. El presente trabajo forma parte del proyecto de investigación «Clero y sociedad en el noroeste de la Península Ibérica (Siglos XV-XIX)», financiado por el Ministerio de Ciencia, Innovación y Universidades (Ref. HAR2017-82473-P). 
vinculándola a los orígenes del cristianismo en la Península Ibérica. De este interés participaron activamente tanto el poder político de la urbe, representando por su regimiento, como el eclesiástico, a cuya cabeza se hallaban los prelados legionenses y su clero capitular. Esta alianza fue estrecha y, en gran medida, respondía a las fuertes conexiones clientelares existentes entre ambos cabildos, donde se hallaban presentes los principales linajes de la capital.

Lo ocurrido en León desde el último tercio del siglo XVI en adelante no es, de todos modos, un comportamiento ajeno a lo observado en el mundo urbano español de la época o incluso a nivel europeo (Kagan, 1995: 49). Las primeras historias de ciudades, que seguían la estela de los panegíricos de urbes de la Italia renacentista, habían irrumpido en el panorama hispano a finales del siglo XV, desarrollándose con fuerza en las dos centurias posteriores, en especial entre el último cuarto del XVI y las primeras décadas del XVII (Quesada, 1992: 5-9). En su desarrollo confluyeron los intereses de las elites locales por prestigiar su ciudad con el propio gusto de la Monarquía por recabar información sobre las principales localidades de sus reinos y señoríos, en el marco de fortalecimiento del poder regio (Pereda y Marías, 2004: 130). Todas estas historias y corografías, por su marcado cariz fabuloso y de exaltación de la ciudad de turno, fueron durante un tiempo despreciadas por los historiadores cuando, precisamente por ese motivo, resultan sumamente interesantes para entender las aspiraciones sociales o políticas de las elites patrocinadoras y el imaginario colectivo en ellas reflejadas (Aranda, 2001: 168).

Siendo pues la composición y publicación de historias locales un comportamiento generalizado en la época, también es cierto que el noroeste peninsular no destacó especialmente en este fenómeno, posiblemente por hallarnos ante un espacio marcadamente ruralizado y con escasos centros urbanos de entidad (Rey, 2015: 54). Aun así, creemos que el caso específico leonés resulta sumamente interesante, adquiriendo durante los siglos de la Edad Moderna unas apreciables dimensiones, teniendo en cuenta su limitada relevancia política, demográfica o económica en el contexto general de la Monarquía Hispánica.

Tras sus orígenes campamentales en tiempos romanos (García, 2004), la ciudad había vivido su momento de máximo esplendor en la Edad Media, entre los siglos X y XIII, cuando se erigió en sede de la corte leonesa, comenzando su declive político a partir de la definitiva unión de los reinos de León y Castilla en aquella última centuria (Estepa, 1977: 144-146; Álvarez, 1992: 41-50; Martínez, 2011: 37-62). Desde entonces la ciudad fue perdiendo paulatinamente relevancia hasta llegar al siglo XVI en una posición discreta en el panorama urbano de la Corona de Castilla. Las bases demográficas de la capital fueron ciertamente modestas durante la Edad Moderna, oscilando entre los 3.846 habitantes de 1591 y los 6.051 de 1787 . A pesar del crecimiento poblacional experimentado entre ambas fechas, León mostró una estructura económica de marcado sabor tradicional. Un centro urbano muy ruralizado, no sólo por constituirse en lugar de residencia de los grupos sociales captadores de rentas, sino también por la importancia del sector primario (Rubio, 1992: 36-44). 
Aún con todo, ese innegable papel secundario de la ciudad en el contexto castellano no implicó, ni mucho menos, una total pérdida de influencia, habida cuenta del mantenimiento de su condición de ciudad con voto en cortes, aspecto para nada baladí, sobre todo durante el siglo XVI y las primeras décadas del XVII. Tal privilegio unido a su carácter de sede episcopal le permitieron mantener cierta relevancia como centro administrativo a nivel local, tejiéndose en la cúspide de su estructura social una elite que consolidó su preeminencia ocupando algunos de los puestos más relevantes del organigrama político y religioso (Pérez y Martín, 2009). Precisamente, como ya señalamos, fueron esos linajes, aliados en muchas ocasiones con el poder episcopal, los más interesados en potenciar la imagen de León a través del patrocinio de una serie de obras impresas que tenían su prolongación en la creación de un minucioso ceremonial público que buscaba amplificar aquel cuidado mensaje. Para tal fin se empleaban algunas fechas señaladas en las que el artificio barroco salía a las calles y plazas o, también, las solemnes exequias de los reyes e integrantes de la familia real. Sirva como ejemplo de las primeras la tradición de las cantareras, a las que luego nos referiremos, y de las segundas los catafalcos erigidos en la iglesia catedral o en San Isidoro en los que, junto al elogio al insigne fallecido, se podía hacer referencia a las glorias de la ciudad (Campos y Viforcos, 1995: 149).

Ciertamente, este intento de prestigiar el pasado y publicitar los múltiples servicios que había desempeñado la urbe para bien de la Monarquía no era original del caso leonés. Pero también lo es que en León hubo, posiblemente, un mayor interés que en otras ciudades de sus dimensiones por potenciar este tipo de instrumentos de propaganda. En este sentido creemos que fueron dos los factores principales que confluyeron para que este fenómeno eclosionase: por un lado, los intereses políticos de las elites y, por otro, los religiosos del poder episcopal e incluso de otros sectores de las Iglesia legionense. En lo que atañe al primer aspecto, el regimiento leonés y más específicamente sus integrantes, veían en este tipo de propaganda una oportunidad para reivindicar un mayor protagonismo de la ciudad en el contexto de la Monarquía. Obviamente, tal protagonismo debería encauzarse a través de un incremento de la presencia de los miembros de sus principales linajes en el complejo entramado administrativo de la Corona, sirviendo para afianzar provechosas alianzas con linajes de otros ámbitos territoriales. Dicho de otro modo, prestigiar a la ciudad era también un medio para poner en valor la importancia de aquella pequeña nobleza que se había consolidado en los resortes del poder de la urbe una vez que las principales casas nobiliarias la habían abandonado para asentarse en la corte.

A este interés de promoción social, del que participaban tanto los regidores como el resto de integrantes de sus linajes repartidos en el cabildo catedralicio, San Isidoro, San Marcos o San Claudio, se une también otro de corte religioso cuyo objetivo último era prestigiar la sede episcopal legionense. Los obispos leoneses, espoleados por el proceso reformista emanado de Trento, estuvieron sumamente interesados en 
potenciar la imagen de su Iglesia, fundamentalmente, en dos aspectos: subrayando su antigüedad, buscando equipararla a otras sedes más importantes y legitimando su carácter exento, que en alguna ocasión había sido cuestionado. Dentro de un panorama generalizado de exaltación de los santos locales como evidencia tangible de las glorias de su Iglesia, los prelados legionenses contaron con el apoyo de unas elites que también la consideraban sumamente eficaz a la hora de prestigiar a la propia ciudad. En consecuencia, esta conjunción de intereses fructificó en una serie de publicaciones que a lo largo de los siglos de la Edad Moderna vieron la luz y que buscaban fornecerse en el refugio de la Historia para sustentar sus argumentaciones.

\section{EL INICIO DEL PROCESO DE VINDICACIÓN: EL LEÓN DE ESPAÑA DE PEDRO DE LA VECILLA}

La obra que inaugura esta política reivindicativa es también, posiblemente, la más valiosa desde el punto de vista literario. Me refiero al célebre «León de España» de Pedro de la Vecilla Castellanos (Vecilla, 1586), libro publicado en Salamanca y que, a pesar de no contar con reediciones posteriores, gozó de cierta fama en sus tiempos. Que era una obra conocida en los círculos lectores cultos de la época queda de manifiesto, por ejemplo, en el hecho de que se cite en el propio Quijote en la célebre escena de la quema de libros, o que ciertos pasajes y personajes fueran recuperados por Lope de Vega para algunas de sus comedias (Fernández, 2003: 187).

El «León» no responde al tipo de historias locales y corografías propias de aquellos tiempos, tanto en lo que se refiere a su estructura como, sobre todo, por el hecho de haber sido compuesta en verso. En este sentido la obra de La Vecilla Castellanos se ha de encuadrar en el contexto del notable desarrollo de la poesía épica que se vivía en el panorama hispano del momento, género, por otra parte, especialmente apto a la hora de plantear, como es el caso, ciertas reivindicaciones políticas o para exaltar glorias pasadas y presentes de una ciudad y de sus linajes (Vilà, 2007: 53). El autor sigue la estela de la obra maestra del género en castellano, La Araucana de Alonso de Ercilla, para presentarnos una historia épica de León en la que se mezclan elementos reales con otros muchos ficticios, emanados de su imaginativo talento o de tradiciones ya consolidadas por entonces, caso del tributo de las cien doncellas o la batalla de Clavijo. Esa combinación de poesía e historia, de realidad y ficción, le lleva a autodefinirse en el prólogo como «historiador poético» o "poeta histórico». Por otro lado, la mezcla entre ficción y realidad era un componente consustancial a la producción historiográfica de la época, hasta el punto de que, como apunta Ofelia Rey, resulta anacrónica la división entre historia y literatura (Rey, 2003: 620).

El libro, dividido en dos partes y veintinueve cantos buscaba, en palabras del propio autor en su dedicatoria a Felipe II, «ver salir a la luz los olvidados sucesos 
$\mathrm{y}$ heroycos hechos de valerosos varones en armas e invencibles pechos de sanctos martyres del antiguo reyno de León», para repararlos «de la injuria que del olvido y tiempo hasta aquí han rescebido». Esa reivindicación de las glorias de la ciudad parte de la certeza de la injusta decadencia que sufría por entonces con «su corona deshecha, sus muros rotos, sus antiguos solares de nobleza gastados, tantos despojos de valerosísimos capitanes cubiertos de polvo y tantos túmulos de católicos reyes por los rincones» (Vecilla, 1586: prólogo). Siendo cierto que esa visión de los muros derruidos es un tópico literario bien conocido (Fernández, 2003: 176), no lo es menos que refleja también un estado de opinión estrechamente vinculado a unas elites que buscan en la reivindicación histórica asumir un papel más relevante en los destinos de la Monarquía. Tal vinculación, por otro lado muy en la línea de otras obras de esta índole (Kagan, 1995: 54), tuvo su reflejo tanto en la propia gestación de la obra como en su posterior publicación.

En lo que atañe al primer aspecto, resulta significativo analizar la nómina de personajes relevantes de la sociedad leonesa de finales del siglo XVI que aparecen reflejados al inicio del libro como autores de una serie de poemas laudatorios. A la cabeza de todos ellos, por su importancia, se sitúa el canónigo de la Iglesia de León y capellán del rey D. Antonio de Obregón y Cereceda, miembro de uno de los principales linajes de la ciudad y hombre de apreciable cultura humanista. Autor de unos Discursos sobre la filosofía moral de Aristóteles (1603), era sobrino-nieto de otro canónigo del mismo nombre reconocido por su sólida cultura erasmista (Rabaey, 2010: 254). D. Antonio había destacado también por su labor de rescate y puesta en valor de viejas reliquias de la catedral caídas en el olvido, caso, por ejemplo, de las del obispo San Pelayo (Martínez, 1982:187).

Otro integrante del linaje, el capitán Tristán de Obregón y Cereceda, regidor de la ciudad, aparece igualmente en el libro como autor de unas redondillas, junto al también capitán Alonso de Tovar, cuya esposa, Antonia de Castro Osorio, estaba emparentada con la condesa de Lemos. A ellos se unen el propio hermano del autor y una serie de clérigos y personajes destacados de la vida cultural de la urbe que, según Escobar (1963: 43), sin aportar refrendo documental alguno, integraban una tertulia literaria. Todos ellos en sus contribuciones poéticas ensalzan el valor de la ciudad y reivindican la recuperación de su gloriosa historia perdida en el olvido. Así, por ejemplo, otro de los participantes, Pedro de Mata, hace hincapié en el papel central del viejo reino de León en el proceso reconquistador frente a los musulmanes, al decir: «León que has tantos reyes producido/ Y tantos reinos has recuperado». O el licenciado Salazar, siguiendo la línea argumental del autor en su prólogo, se lamenta del escaso eco que en aquellos tiempos tenían las glorias del reino: «Real León que tantos siglos mudo/(no sin mysterio) te ha tenido el cielo/cubierto siempre de un cerrado velo/y el cuello preso con estrecho nudo». Pero la implicación de las elites no se queda exclusivamente en esa participación en la obra. También se extiende 
al patrocinio de la misma. Fue el propio regimiento de la ciudad el que costeó su impresión en Salamanca y, en su nombre, los regidores Tristán de Obregón y Pedro Castañón Villafañe, ambos procuradores por la ciudad en cortes, los que obtuvieron la licencia regia para tal fin.

Las referencias históricas del León de La Vecilla son, en no pocos casos, inverosímiles. Algunas, fruto de la lectura o reinterpretación de autores clásicos y crónicas medievales y otras del ingenio del propio autor. Pero, al margen de la escasa verosimilitud del relato, introduce una serie de personajes y hechos que calarán en las obras posteriores $y$, por ende, en la memoria colectiva leonesa. Por ejemplo, los catorce primeros cantos de la obra, lo que supone la práctica totalidad de la parte primera, se centran en la época romana. Incluso, antes de comenzar la narración épica de los acontecimientos, incluye en el libro unas supuestas inscripciones epigráficas que hacen referencia a un tal Curieno, supuesto caudillo hispano que daría nombre a la comarca leonesa del Curueño y que se habría rebelado, junto con otros líderes, contra los romanos, protagonizando algunas de las hazañas épicas narradas en los primeros capítulos. Obviamente, ni los personajes ni las referencias transcritas tienen viso alguno de realidad, como ya señalara en su tiempo Francisco Masdeu (17831805: 673). Sin embargo, se toman como pretexto para subrayar el carácter indómito y guerrero de aquellos primeros leoneses que antes incluso de la fundación de la ciudad mostraron su valentía y arrojo frente a las legiones romanas. Virtudes que desde entonces los caracterizarán hasta los tiempos contemporáneos, aplicándoles el tópico harto extendido en la época para todos los españoles de que los leoneses eran más duchos en el manejo de las armas que en el de la pluma (Fernández, 2003: 177). Esa firme lucha contra el invasor que demostrarán tanto frente a los romanos como, posteriormente, ante los musulmanes, constituye otro tópico bastante extendido en obras de esta índole para el ámbito norteño (Orella, 1999), como elemento que refuerza la «españolidad» de su población frente a aquellos territorios en los que la presencia «extranjera» fue más permanente.

Otro objetivo es, sin duda, subrayar la antigüedad de la ciudad, cuyo antecedente más inmediato sitúa en «Sublantia Flor», urbe fundada por el filósofo Mercurio Trimegisto «sapiente rey del término egipciano». Fueron las legiones responsables de su arrasamiento en tiempos de Trajano las que, posteriormente, fundaron León. Esta relación le sirve para cumplir dos objetivos: por un lado, recalcar el carácter clásico de la ciudad, lo que sin duda para la época trae consigo un plus de prestigio y, por otro, subrayar la existencia previa de los leoneses o «españoles» y su vinculación con fundadores de origen griego, tan apreciados en las historias locales de otras ciudades del ámbito castellano (Morgado 2009: 948; Cuart, 2011:33-39). La identificación de Sublantia como primera fundación de León y su relación con el reinado de Trajano, la recoge La Vecilla de algunas crónicas medievales, en especial la Najerense y la de Pelayo de Oviedo (González, 1997: 194-196) o del contemporáneo Esteban de 
Garibay (1571: vol. I, 210 y 235) y tal idea va a cuajar a posteriori, reflejándose en la obra de Atanasio Lobera o en La pícara Justina, cuyo autor, con la ironía que le caracteriza afirmaba:

«Esta es la campaña donde los antiguos dicen que fue la primera fundación de León cuando ella estaba en su flor, en hecho y en nombre, pues se llamaba entonces Sublantia Flor. Mas el aire de la mudanza, que todo lo derriba, lo arrancó de cuajo y mudó al sitio donde agora está, tan linda de lejos como fea de cerca, trocado el nombre de Flor y su belleza en la ferocidad y en el nombre de León, junto con el rigor del frío y la melancolía de las lluvias y humedades en que, por lo riguroso y melancólico, representa la fiereza del león y la melancolía de la cuartana» (López de Úbeda, 2005: 262).

El León romano, que contaba con un poso histórico real y palpable para los contemporáneos, propiciaba asimismo la exaltación de la ciudad como uno de los primeros focos de irradiación del cristianismo en la Península, lo que conllevaba también remarcar la antigüedad de su Iglesia. Esta línea de actuación tampoco es novedosa, puesto que existen, como veremos, importantes antecedentes medievales, amén de ser una pretensión generalizada en las historias locales de la época. Pero, sin duda, su difusión adquiere ahora mayores dimensiones, tanto por los efectos amplificadores de la imprenta como por el propio contexto de reforma que se vive en la Europa católica postridentina. Esta identificación de León y su Iglesia con las primeras comunidades cristianas se personaliza en la figura del mártir San Marcelo y su extensa familia.

El centurión, su esposa y sus doce hijos también mártires, ocupan un lugar preferente en la primera parte de la obra, narrándose sus gloriosos sacrificios, comenzando, como no podía ser de otro modo, por el cabeza de familia y sin dejar tampoco de hacer referencia a la santidad de su esposa Nonia, la única que no ostentará la palma martirial. El culto leonés a este mártir romano se constata desde el siglo XI en adelante, apareciendo antes relacionado en los calendarios con la ciudad africana de Tánger (García, 1966: 244). Su irrupción en el panorama devocional legionense se ha de relacionar con un intento de la catedral de fortelecerse en el contexto de su rivalidad con la Iglesia de San Isidoro y la sede toledana (Pérez-Embid, 2002: 186). Es pues desde entonces cuando adopta tal naturaleza, siendo mencionado en el Antifonario de la catedral junto a otros mártires, entre los que destacan Claudio, Lupercio y Victorico, a los que se les vincula entonces por vez primera como hijos suyos, parentesco que a pesar de su inverosimilitud cuajará. Desde entonces y a lo largo de las centurias posteriores la prole del centurión irá incrementándose hasta alcanzar a comienzos de la Edad Moderna el simbólico número de doce (Martínez, 2017: 381). 
La dificultad que entrañaba vincular al supuesto santo leonés - «vezino de León y en él criado» dice Pedro de la Vecilla - con su martirio en Tánger se solventó, siguiendo los textos previos medievales, señalando que, aunque la profesión de fe y rechazo del culto al emperador se realizó en su ciudad de origen, fue enviado a la urbe norteafricana a sufrir martirio (Vecilla, 1586: Canto VIII; Pérez-Embid, 2002: 185). Aquel argumento, ciertamente endeble, recibió un fuerte espaldarazo a finales del siglo XV, concretamente en 1493, con la solemne traslación de los supuestos restos del santo desde Tánger, tras la conquista portuguesa de aquella plaza. El padre Atanasio de Lobera narra con mayor detalle aquel episodio, desarrollado un 29 de marzo, con la presencia de Fernando el Católico y lo más granado de la nobleza cortesana y que, como no podía ser de otro modo, estuvo jalonado de innumerables hechos milagrosos que corroboraban la inequívoca naturaleza santa de aquellos restos humanos (Lobera, 1596: 270).

El martirio del centurión evidenciaba la existencia de una comunidad cristiana en tiempos remotos y, por ende, la antigüedad de la Iglesia legionense. Pero Pedro de la Vecilla iba más allá, al convertir a los hijos de San Marcelo en los doce pilares principales de la expansión de la verdadera fe por la Península Ibérica. Tres de ellos, Fausto, Januario y Marcial morirían martirizados en Córdoba, otros dos, Germano y Servando en Mérida; sus hermanos, Facundo y Primitivo, en Sahagún de Campos, mientras que Emeterio y Celedonio sufrirían tormentos en Calahorra. Finalmente, los tres hijos mayores ya mencionados, Claudio, Lupercio y Victorico, serían martirizados en la propia ciudad de León.

Dejando al margen la imposible ligazón familiar de todos estos santos, que ya había sido fijada en tiempos medievales por Lucas de Tuy, algunos de ellos sí es cierto que contaban con arraigada devoción en tierras leonesas, al menos desde la Plena Edad Media. Por ejemplo, ya hay constancia del culto a los sahugunenses, ligado al desarrollo del monasterio benedictino de aquella villa, en el siglo X (Pérez-Embid, 2002: 61; Farmhouse, 2011: 212). En lo que atañe a Claudio, Lupercio y Victorico, su presencia parece fijarse a partir de 1173, tras la visita del cardenal Jacinto, legado del papa Alejandro III, a la corte del rey leonés Fernando II (Campos, 2006). Como en el caso anterior, este culto quedará ligado también a un monasterio benedictino, el de San Claudio, ubicado a extramuros de la ciudad (Martínez, 2019). De igual modo, en lo que se refiere a los mártires calagurritanos, la adscripción leonesa nos remite también al mundo medieval, incluso a fuentes ajenas a las vinculadas a la Iglesia legionense. Así ya en la «passio» de dichos santos, incluida en los pasionarios de Silos y Cardeña (siglo VIII) o en el Martirologio de Lyon (siglo IX) se les relaciona con la ciudad (González, 1998: 275; González, 2000: 372).

Parece pues que Pedro de la Vecilla se limita a enriquecer con su talento poético e inventiva la narración de los martirios, partiendo de la base de los textos y tradiciones medievales que continuaban teniendo vigencia en la época. A veces, como 
en los casos ya referidos, la vinculación de los mártires con la Iglesia legionense, si bien fruto de una inventio, venía de lejos y contaba incluso con cierto consenso a nivel erudito, viéndose respaldado por reputados autores de la época, caso del padre Mariana (1780: 206) Pedro de Ribadeneira (1716: 559) o Alonso de Villegas. Sin embargo, en lo referido a Fausto, Januario, Marcial, Germano y Servando, las dificultades se incrementaban, al existir otras localidades que disputaban su naturaleza. De hecho, el propio Villegas, sin negarla en rotundo, dejaba en suspenso la adscripción a la ciudad de cinco de los doce hijos de San Marcelo (1585: 380-383). Menos sutiles eran las respuestas de otros eruditos locales: en su Emporio del Orbe, Fr. Jerónimo de la Concepción (1690: 237) recogía la tradición del santo y su descendencia, pero haciéndolos a todos naturales de Asta, en las proximidades de Jerez de la Frontera, como recurso en este caso para engrandecer la antigüedad de la Iglesia gaditana y ensalzar a sus santos patrones, precisamente Germano y Servando. Línea que continuará en el siglo XVIII el canónigo de Cádiz Francisco Melitón que partiendo de una erudición ya más moderna llega a cuestionar la propia naturaleza leonesa de San Marcelo (Melitón, 1798: 8).

Pero el centurión, su esposa e hijos, no serían los únicos ejemplos de santidad que ofreció León al orbe. También en el libro se hace especial mención al martirio de San Vicente, supuesto abad del monasterio de San Claudio en tiempos de dominio suevo (Vecilla, 1586: Canto XVII). La narración de los acontecimientos, con innegable habilidad literaria, la pone el autor en boca de un ermitaño tras un casual encuentro con el rey Don Pelayo. La historia resulta sumamente sugerente, en primer lugar, porque vuelve a recalcar la inquebrantable defensa de los dogmas de la verdadera fe desde tiempos remotos por parte de los leoneses, en este caso frente a los arrianos. En segundo, porque sitúa en la urbe un supuesto concilio presidido por el monarca Reciliano, acontecimiento históricamente insostenible pero que contribuye a marcar la antigüedad de su Iglesia. De nuevo, Pedro de la Vecilla se limita a versificar un culto que bebe de las tradiciones e inventios medievales y de las que, poco antes de la publicación de su obra, había hecho referencia el propio Ambrosio de Morales en su conocido viaje por los reinos de Galicia, León y principado de Asturias (Morales, 1765: 56). Sin embargo, no hay en la obra de La Vecilla referencia directa alguna a otros santos del cenobio, en especial a San Ramiro, el supuesto prior del monasterio que también habría sido martirizado por los arrianos poco tiempo después del abad. La razón de esta ausencia está, sin duda, en la circunstancia de que el fomento del culto a este santo es posterior a la publicación de su libro. De hecho, el propio escritor participó activamente en 1597 en la recuperación de las reliquias del mismo halladas en aquel monasterio leonés, actuando como testigo en la probanza abierta entonces por el obispo Moscoso a fin de dilucidar la santidad de los restos humanos encontrados. En sus respuestas, Pedro de la Vecilla, que contaba por entonces con unos cincuenta y cuatro años, afirmaba haber narrado el martirio del prior y otros doce monjes «en la tercera parte

Ediciones Universidad de Salamanca / అ@@ Stud. his., H. ${ }^{a}$ mod., 41, n. 2 (2019), pp. 123-153 
de su libro que tiene ya licençia del rey para imprimirlo» ${ }^{2}$. Sin embargo, parece que esta continuación de la obra nunca llegó a publicarse.

Si los orígenes romanos despertaron en los leoneses muy pronto el sentimiento cristiano, esa fe incorruptible unida a su indómito espíritu guerrero, hará que la ciudad se convierta en el principal bastión frente al Islam poco después de producirse la «general destruición de España». En los cantos XV y XVI, con los que concluye la primera parte de la obra, se narra el durísimo sitio que sufrió la ciudad frente las huestes musulmanas, aprovechando la épica narración para intercalar las hazañas de diferentes defensores cuyos nombres aluden de un modo poco sutil a algunos de los más importantes linajes de la urbe. Así aparece un tal Lorencino que hace referencia a los Lorenzana, un Florios a los Flórez, un Galbarito a los Garabitos o una aguerrida dama de nombre Ana «de los claros Quinones su apellido» - referencia a los Quiñones - cuya valentía le hizo obtener el perdón del líder moro.

Pero, lógicamente, tras la heroica defensa cristiana, la conquista musulmana fue efímera, hasta el punto de que La Vecilla responsabiliza al propio Don Pelayo de la recuperación de la ciudad. En efecto, tras la milagrosa victoria del Monte Auseba, el rey, consciente de la importancia de la urbe, se lanzó a su recuperación, destacando en aquel episodio la figura de un bravo guerrero, Osorio - de nuevo alusión a los linajes de la ciudad - que infiltrándose por las murallas logró abrir las puertas para que penetrase el ejército libertador. Solamente pues cuatro años después de su pérdida, León volvía a manos cristianas en un acontecimiento que hábilmente el autor ligaba con la famosa batalla de Covadonga, a fin de vincular a la ciudad con los orígenes propios de la Reconquista.

Una vez narrado este hecho de armas de capital importancia y tras hacer algunas menciones a otros monarcas posteriores o incluso relacionar a los leoneses con la derrota de Carlomagno en Roncesvalles, La Vecilla concluye su obra haciendo referencia a otro episodio mítico de los tiempos medievales: la batalla de Clavijo y el fin del tributo de las cien doncellas. En el canto XXIV se narra cómo fueron las propias leonesas las que lograron despertar el corazón de Ramiro I para acabar con tan injusto y humillante pago. La decisión regia se tomó ante el consistorio de la capital, denominado «senado» por el poeta y en el debate que la precedió, de nuevo un integrante de la elite leonesa, D. Luis Osorio, señor de Villalobos y, por ende, antepasado de los marqueses de Astorga, desempeñó un lugar relevante. La consecuencia de aquel desacato a la autoridad cordobesa será la guerra en la que participaron activamente los antepasados de los regidores - Osorio, Ponce de León, Vigil y Quiñones, Guzmanes, Lorenzana... - o los del propio autor. La contienda concluirá en la famosa batalla de Clavijo, en la que el Apóstol Santiago intervendrá propiciando la victoria cristiana, instaurándose en agradecimiento el Voto, «justa

2. ADL (Archivo Diocesano de León), Monasterio de San Claudio, Carpeta 355.

Ediciones Universidad de Salamanca / @@@ Stud. his., H. ${ }^{a}$ mod., 41, n. 2 (2019), pp. 123-153 
promesa y muy debido pago» (Cantos XXVII y XXVIII). La inclusión en las obras de los historiadores leoneses de estos episodios míticos de origen medieval, siguiendo casi a pies juntillas lo señalado en su momento por Lucas de Tuy (Rey, 1985: 28-29), refleja la comunión de intereses entre lo narrado en el apócrifo privilegio del Voto y el protagonismo que en él desempeñaba la ciudad de León.

Tras la narración de la batalla la obra finaliza con el encuentro del monarca con un anciano llamado Leonnino que le muestra sus profecías, un resumen de los hechos gloriosos que vivirá León en los siglos posteriores: la expansión del reino, la construcción de la catedral, las razias de Almanzor, la conquista de Baeza tras la ayuda de San Isidoro - en un episodio deudor del de Clavijo - hasta llegar a los reinados de Carlos I y Felipe II como continuadores de tan regia estirpe. Aprovecha el autor, en palabras del mago, para ensalzar la belleza de la urbe, muy en la línea corográfica de la época, haciendo especial hincapié en la importancia de sus templos y destacando entre todos el catedralicio.

\section{DOS CRONISTAS DE LA IGLESIA DE LEÓN: EL OBISPO TRUJILLO Y FRAY ATANASIO DE LOBERA}

En tiempos de la publicación de la obra de Pedro de la Vecilla llevaba ya unos años gobernando la sede legionense el obispo Francisco Trujillo (1578-1592). Prelado de apreciable cultura y afán reformista, había sido antes catedrático de Artes en Alcalá y participado en Trento como integrante de la comitiva del obispo D. Andrés Cuesta, protector suyo. Fue un firme impulsor de las disposiciones tridentinas en la diócesis, destacando en su afán por la creación de instituciones educativas. Su intento de fundación de un seminario conciliar fue torpedeado por la férrea oposición del cabildo catedralicio con el que sostuvo importantes disputas a lo largo de su episcopado, lo que le llevó como alternativa a la fundación en Alcalá de un colegio menor, bajo la advocación de Santa María de Regla y los santos Justo y Pastor (Posadilla, 1899: 168-173).

Poco tiempo después de la publicación de la obra de Pedro de la Vecilla, el prelado legionense terminaba de redactar su «Historia de la Santa Iglesia de León», obra que no llegará a imprimirse pero que no por ello fue desconocida, tanto para su contemporáneo, el padre Atanasio Lobera como para el agustino Manuel Risco en el siglo XVIII. Este último la consideraba una obra recomendable, por haber sido la primera que acometía un estudio desde los orígenes de la Iglesia legionense, disculpándole ciertos errores a la hora de manejar algunos documentos «que en su edad se reputaban por auténticos y en la nuestra se desprecian por los mejores críticos» (Risco, 1784: prólogo). Sea como fuese, en aquella centuria dieciochesca hubo algún proyecto, aunque infructuoso, por rescatar del olvido la obra. Así, en 1778 el canónigo archivero de la catedral Pedro Manuel Hernández con notas suyas 
y de su predecesor, Carlos Espinós del Pí, intentó publicarla, pero las enmiendas señaladas por la Academia de la Historia para lograr la autorización condenaron el proyecto al fracaso (Muñoz y Romero, 1858: 151).

El origen de este manuscrito del que se conservan actualmente varias copias en diferentes bibliotecas y $\operatorname{archivos}^{3}$, parece que estuvo en la solicitud que había hecho al obispo de León García de Loaysa y Girón para que le remitiera una sucinta información sobre la antigüedad de la diócesis, su carácter exento y el listado de sus obispos. El encargo de aquel humanista, quizás en el contexto de la redacción de su famoso Collectio Conciliorum Hispaniae, lo cumplió el prelado auxiliado por sus dos secretarios, Baltasar de Peñaranda y el licenciado Segura. Pero una vez recopilada la información requerida, decidió elaborar una obra de mayor enjundia con el objetivo claro de defender la antigüedad y privilegios de su Iglesia que, como él mismo refiere, se habían puesto en entredicho por algunos autores.

La obra del obispo Trujillo, a diferencia de la de Pedro de la Vecilla, se centra más en la Iglesia que en la ciudad de León, si bien la defensa de la primera le lleva también a encumbrar a la segunda. El manuscrito presenta una apariencia erudita con abundantes referencias a autores clásicos y contemporáneos y detallando la información documental rescatada del archivo catedralicio. Resulta, no obstante, significativo que no se haga alusión alguna al León de España, quizás por no considerarla el prelado una obra propiamente histórica. La combinación de autores de renombre, caso del padre Mariana, con crónicas medievales o sus interpretaciones personales sobre determinados episodios espinosos, en muchas ocasiones de endeble consistencia - caso de la antigüedad de su obispado o del martirio de San Marcelo, por poner dos ejemplos significativos-, redunda en su escasa credibilidad que explica la posterior censura por parte de la Academia.

De todos modos, al margen de ese fingido carácter erudito, la obra del prelado resulta de alto interés, al mostrar los principales objetivos de los obispos legionenses en su proyección propagandística que, ni mucho menos, inicia Trujillo, sino que arranca de tiempos medievales. Como el propio obispo señala en sus primeras páginas, éstos son la defensa de la antigüedad de su Iglesia y su carácter exento desde los propios orígenes, atendiendo a la circunstancia de que ambas cuestiones habían sido puestas en tela de juicio desde hacía tiempo. De hecho, la orgullosa defensa de los privilegios de la Iglesia legionense frente a metropolitanos y a otros obispos había generado no pocas tensiones. La más reciente, como narra el propio autor, la protagonizada por su antecesor Juan de San Millán (1564-1578) y el obispo de Oviedo, que gozaba del mismo privilegio, Gonzalo Solórzano, en el concilio

3. Para nuestro trabajo hemos empleado, fundamentalmente, el manuscrito existente en la Biblioteca Nacional, copia del ejemplar existente en la Academia de la Historia. B.N. (Biblioteca Nacional), Manuscrito $n^{\circ} 5.560$. 
compostelano, celebrado de Salamanca en 1565. Ante la oposición de los demás prelados a reconocerles a ambos su preeminencia tras el metropolitano, amenazaron con abandonarlo, logrando de este modo su objetivo (Trujillo, 1590: 38; Risco, 1787: 127). No era la primera vez que se ponía en cuestión ese peculiar privilegio de la Iglesia legionense. En tiempos anteriores, sus obispos habían salido airosos de las presiones de los arzobispos de Toledo para lograr convertir a su diócesis en sufragánea (Mansilla, 1980: 291-296).

Ambas cuestiones pues, constituyen el principal hilo argumental de la obra de Trujillo, tratando de sostenerlas mediante una serie de referencias documentales o de citas de autores del pasado que distan mucho de ser convincentes, atendiendo a las dificultades para hallar testimonios documentales que mencionasen a la diócesis legionense anteriores a la segunda mitad del siglo IX, que es cuando efectivamente se erige (Bango Torviso, 2004: 47-49). De hecho, el propio Trujillo reconocía que en el archivo de su Iglesia no existían escrituras previas al reinado Ordoño II.

Retomando en cierta medida el argumento esgrimido por Pedro de la Vecilla, el obispo fija en los orígenes romanos de la urbe las raíces de la antigüedad de su Iglesia. Convierte a León en la principal ciudad romana del noroeste peninsular, cabeza de su provincia lo que, unido a la existencia desde los primeros tiempos de mártires cristianos reconocidos, le lleva a concluir que, en buena lógica, ya por entonces había de contar con obispos. El prelado defiende esta postura amparándose en la ambigua información ofrecida por la epístola de San Cipriano, las crónicas medievales o los contemporáneos Vaseo y Garibay y contradiciendo la opinión de Ambrosio de Morales.

Como ejemplo de la asentada presencia de una comunidad cristiana en la ciudad presenta a San Marcelo y sus doce hijos, yendo incluso más allá que Pedro de la Vecilla, al considerar que los santos Facundo y Primitivo no eran descendientes del centurión aunque sí leoneses, sufriendo el martirio antes que su supuesto progenitor, constituyéndose en fieles testigos «de la christiandad desta ciudad de abuelta de los años de nuestro redemptor 150 o antes» (Trujillo, 1590: 24 vto.). Al desligar a estos dos santos de la descendencia de San Marcelo, como había apuntado el padre Mariana, los sustituye por otros dos mártires cordobeses, Acisclo y Victoria, pasando a estar compuesta la prole no por doce hijos, sino por once hijos y una hija.

Una vez formulada la idea de la rapidez con la que se asentó el cristianismo en la ciudad y de la también pronta erección de una sede episcopal en la misma, Trujillo sitúa de igual modo en aquellos remotos tiempos la obtención de la exención de metropolitano para la diócesis. Para llegar a esa conclusión no emplea aval documental alguno sino sus propias impresiones. La circunstancia de que León fuera una importante plaza fuerte con un abundante contingente militar procedente de la propia Roma, persuadiría a los sumos pontífices a conceder tal privilegio (Trujillo, 1590: 31 vto.). Precisamente, dicha exención explicaría la problemática ausencia de 
los obispos legionenses en los concilios antiguos o en el parroquial suevo, solucionando de este modo uno de los principales escoyos para justificar la antigüedad de la diócesis.

A la existencia de una diócesis en la práctica desde los albores del cristianismo se le unía su permanencia a lo largo de los siglos, tanto en los difíciles tiempos de gobierno arriano como tras la conquista musulmana. Pues ni en el breve dominio islámico desapareció, adquiriendo mayor fuerza una vez recuperada la ciudad, sobre todo desde el momento en que los monarcas asturianos se trasladaron a ella, convirtiéndola en el principal bastión cristiano peninsular. De hecho, afirma Trujillo, «León conquistó todas las otras ciudades y reynos de España como se vee en las historias della», razón por la cual el prelado defiende con ardor en el capítulo XLIV la precedencia de la ciudad de León sobre Burgos en las cortes castellanas. Como en el caso del «León de España» también en el manuscrito se subraya como episodio relevante de la historia leonesa la batalla de Clavijo, siguiendo en esencia el relato tradicional del mismo y resaltando el papel desempeñado por la ciudad.

La obra de Trujillo finaliza con un memorial de los santos de la diócesis, en la que se narra brevemente sus vidas. La inclusión de los mismos la justifica el prelado atendiendo a su importancia tanto en número como en calidad y antigüedad «mostrándose en ella la gran fee y su tan firme religión christiana desde tan antiguos tiempos» (Trujillo, 1590: 287 vto.). El elenco de santos leoneses pues contribuye firmemente a prestigiar la urbe, vanagloriándose su pastor de no haber ciudad española que le haga sombra, a excepción de Zaragoza, que podía tener un mayor número de santos antiguos mas no de igual calidad. De la misma manera también se defiende la idea ya sugerida en el «León de España» de la ciudad como foco de extensión del cristianismo desde sus propios orígenes y de bastión de la fe frente a los infieles.

Por otro lado, la relación respondía al deseo de Trujillo de fijar el santoral legionense tras las concesiones de Pio V y Gregorio XIII para que las diócesis pudieran rezar a sus santos propios en los oficios, tras la aprobación del breviario común para todo el orbe católico. A tal fin, el obispo y los diputados del rezo del cabildo catedralicio, compusieron el recuento que se incluye en la obra. En él se enumeran dieciocho mártires, de los cuales dieciséis corresponden a las persecuciones romanas, comenzando por los más antiguos, Facundo y Primitivo, y continuando con San Marcelo y su numerosa progenie, así como San Vicente, mártir abulense pero con reliquias en la ciudad. A ellos se unía el abad del mismo nombre, martirizado en tiempo de los suevos y el joven San Pelayo que sufrió persecución por parte de los sarracenos. Además, se incluían un total de nueve confesores, comenzando por Santa Nonia, esposa de San Marcelo y continuando por Santo Toribio, obispo de Astorga, San Isidoro de Sevilla, los obispos Froilán, Pelagio y Alvito, santo Martino, religioso del convento de San Isidro, San Ramiro, prior de San Claudio y el beato de 
Valcabado. Sin embargo, Nonia, Pelagio, Alvito, Ramiro, Martino y Beato, aunque reverenciados por tradición, no quedaban incluidos en los rezos.

El sucesor del obispo Trujillo en la silla episcopal legionense, Don Juan Alonso Moscoso (1593-1603), sin duda tomando como referencia este tratado inédito, encomendó al monje cisterciense Fr. Atanasio Lobera la redacción de una nueva historia de la ciudad y su Iglesia, que bebe directamente de las dos obras anteriormente analizadas, como el propio autor reconoce. Lobera era un religioso con evidente pericia y experiencia en este tipo de trabajos, con los que buscaba una notoriedad que le llevaría a ser nombrado cronista real y, no menos importante, obtener apreciables cantidades de dinero (Rey, 2015: 59). Esa es la razón que le llevó a solicitar un apoyo económico del consistorio leonés que no debió de producirse, pues la dedicatoria de su obra se restringe al prelado y a su deán y cabildo. Parece que en principio el objetivo del cronista era escribir la historia de San Froilán, patrón de la diócesis, pero el propio obispo Moscoso le animó a que realizara también un somero estudio sobre las antigüedades de la ciudad y su Iglesia. Y así lo hizo, reconociendo el propio autor que su «tratadillo» era «un breve espithome de algunas cosillas particulares» pues la redacción de una historia de la ciudad «era negocio de muchos años y de muchos libros» (Lobera, 1596: 165). Quizás su incapacidad para recabar una mayor financiación le llevó a limitar las pretensiones de la obra, aunque más bien parece un simple recurso literario.

El cronista demuestra a lo largo del texto un buen conocimiento de las crónicas del Medievo, así como de la historiografía contemporánea, si bien, como ya habían realizado sus ilustres predecesores, no tiene escrúpulos en cubrir los importantes vacíos de información con elucubraciones sin refrendo documental alguno o en echar mano de tradiciones siempre tendentes a engrandecer la historia leonesa. Estos recursos le valdrán el elegante reproche de Jovellanos cuando señaló que el libro «si tuviera buena crítica como buen estilo fuera muy estimable» (Díaz-Jiménez, 1925: 18).

Salvo por algunos matices, las líneas argumentales de La Vecilla y Trujillo, que defendían a León como uno de los principales centros difusores del cristianismo en la Península Ibérica - con sede propia desde época romana - y como cuna de la monarquía española, constituyen el principal soporte de la obra de Lobera. A diferencia del prelado, el monje bernardo no tiene inconveniente en citar la obra de Pedro de La Vecilla, siguiendo de hecho a este autor a la hora de tratar los orígenes de la ciudad y sus conexiones con Sublancia Flor, adornándola con referencias a autores clásicos, como Tito Livio, o a reputados eruditos más o menos contemporáneos, caso de Juan Vaseo o Marsilio Ficino, sin olvidar a Florián de Ocampo y las alusiones inevitables al tubalismo. También, como defendía Trujillo, el cronista convierte a León en sede regia y cabeza de reino durante el dominio suevo o, siguiendo a Lucas de Tuy, afirma que durante la conquista musulmana fue una de las pocas plazas que ofreció resistencia, teniendo que ser tomada por hambre tras 
un largo sitio. De igual modo, contradiciendo al padre Mariana, responsabiliza al propio Pelayo de la recuperación de la ciudad, manteniéndose muy poco tiempo en manos infieles y convirtiéndose de nuevo en sede regia, si bien la corte no se asentaría allí definitivamente hasta Ordoño II.

Como no podía ser menos, también en el libro desempeña un papel relevante a la hora de marcar la importancia de León en el proceso reconquistador la cuestión de Clavijo y el tributo de las cien doncellas. En este sentido, el monje, como ya señaló hace tiempo Ofelia Rey, aunque comienza presentando una serie de apreciaciones de carácter crítico tanto frente al pretendido tributo como al propio documento del Voto de Santiago, acaba aceptándolo con ciertos matices, señalando que, si bien existió tal pretensión por parte de los musulmanes, ningún rey cristiano lo permitió, ni siquiera el denostado Mauregato (Rey, 1985: 81). De igual modo, encuentra dificultades en el propio documento del Voto, adoptando el monje una actitud reservada, más en lo que atañe a su cronología, que considera posterior, que a la realidad de aquellos teóricamente históricos acontecimientos. En este sentido, estima más factible que tuvieran lugar durante los reinados Ramiro II o Ramiro III que con Ramiro I, atendiendo a las incoherencias cronológicas detectadas en el mismo.

Sea como fuere, como el propio autor afirma, lo importante es el acontecimiento, que marca la relevancia de la ciudad y no la fecha en la que tuvo lugar. Poner en tela de juicio la batalla y la participación leonesa en la misma resultaría completamente improcedente en una obra precisamente sufragada desde León. De hecho, Lobera no escatima elogios en sus referencias a algunos linajes de la ciudad supuestamente participantes en aquel magno hecho de armas y que, amén de copar las regidurías, también ostentaban un lugar preeminente en el cabildo catedralicio. Comenzando con los Lorenzana - uno de cuyos integrantes, Cristóbal Rodríguez de Lorenzana era entonces arcediano de Mayorga - y continuando con los Osorio - marqueses de Astorga - o los Tejada. Incluso no tiene repugnancia a incluir entre aquellos míticos guerreros vencedores de los moros a los integrantes de su propia familia (Lobera, 1596: 202-212). También recalca, como había hecho Trujillo, la excepcionalidad de que tanto el monarca como los marqueses de Astorga fuesen canónigos de la Iglesia de León, merced a una supuesta concesión pontificia tras la batalla. Y no se olvida de la célebre ceremonia de las cantaderas que, como tradición, es considerada otra evidencia de aquel episodio bélico.

La antigüedad de su Iglesia es otro de los pilares de la obra de Lobera, fundamento del patrocinio episcopal. Los argumentos esgrimidos por Trujillo son recogidos por el cisterciense, tanto en lo que atañe a la identificación de los primeros mártires leoneses con una supuesta diócesis ya establecida en aquellos remotos tiempos, como en lo que se refiere a la misiva de San Cipriano que haría una velada referencia a la existencia de un obispo en León, así como otros confusos documentos posteriores. Lobera, como hiciera con anterioridad Trujillo, critica las afirmaciones del padre 
Mariana que descarta la existencia del obispado legionense hasta el reinado de Ordoño II, así como su remota exención. También lo hace cuando aquel cuestiona la antigüedad del templo catedralicio, cuya erección, siguiendo punto por punto a Trujillo, la atribuye a dicho monarca. Al igual que el prelado, se esfuerza en incorporar a la obra un listado de los obispos legionenses desde los supuestos orígenes de la diócesis, a fin de fortalecer esa idea.

Como colofón y siguiendo en gran medida la estructura de la obra de Trujillo, realiza una semblanza hagiográfica de los principales santos leoneses, ocupando lugar preeminente, una vez más, San Marcelo y sus doce hijos que en el caso de Lobera son los marcados por la tradición medieval y que ya habían sido referidos por La Vecilla, distanciándose pues de la idea de Trujillo de no considerar a Facundo y Primitivo como descendientes del centurión. De nuevo también entre los mártires se menciona al abad San Vicente, al prior Ramiro - aunque muy brevemente- y al joven San Pelayo. En cuanto a los obispos tenidos por santos, junto a Alvito, Pelagio y Froilán - al que confunde con otro prelado del mismo nombre, pero un siglo posterior (González, 2005: 72) - incorpora asimismo a un san Cibrián, rescatado del libro de los milagros de San Isidoro de Lucas de Tuy. También menciona a Santo Martino y, por supuesto, al propio santo hispalense. Por el contrario, obvia la mención a Santo Toribio, quizás por haber sido obispo de Astorga, a Santa Nonia y al beato de Valcabado. A esta relación se une la de monarcas enterrados en la ciudad, como evidencia de la estrecha vinculación entre la Corona y León desde tiempos inmemoriales.

\section{LOS SIGLOS XVII Y XVIII}

El interés de la Iglesia y el regimiento leonés en el último tercio del siglo XVI por promocionar su historia, tanto civil como eclesiástica, se contextualiza, como ya hemos señalado, en un período especialmente fecundo en este tipo de manifestaciones a nivel peninsular. La imprenta, a la que llegaron dos de las tres obras mencionadas, era desde luego un interesante escaparate para defender los privilegios y las glorias pasadas de la urbe o para estimular las peculiaridades locales en una época de fortalecimiento de la monarquía. Pero, desde luego, no era el único altavoz. Esta producción impresa y manuscrita tenía su prolongación más evidente en el propio ceremonial público que se desarrollaba en la ciudad a lo largo de los siglos de la modernidad. En las exequias fúnebres y en las propias comunicaciones con los monarcas, en su condición de ciudad con voto en cortes, el regimiento trataba de transmitir ese mensaje, haciendo especial hincapié en recalcar su papel de cabeza de reino y procurando que los monarcas tomasen conciencia de su condición de herederos de una antiquísima estirpe cuyo origen estaba precisamente en León. En este sentido, por ejemplo, los responsos anuales rezados en el panteón de los reyes 
de San Isidoro, o las exequias regias en las que se hacía alusión al reino de León, caso de la de Mariana de Austria, no dejaban de tener un claro cariz reivindicativo (Campos y Viforcos, 1995: 121-122 y 149-150). Lo mismo sucedía en las solemnes proclamaciones de los monarcas como, por ejemplo, la de Carlos II, narrada profusamente por el marqués de Fuenteoyuelo y en la que el regimiento, en nombre de la ciudad y su «nobilísimo reino», aclamaba públicamente al nuevo rey por las calles y plazas de la capital (Cabeza de Vaca, 1693: 109-118).

Junto al origen de la monarquía, la raigambre del cristianismo en la ciudad quedaba sustentada fundamentalmente en la figura de San Marcelo y sus hijos, en especial Claudio, Lupercio y Victorico. El centurión había sido proclamado patrón de la ciudad, por lo que, en el día de su fiesta, el regimiento procesionaba junto al cabildo de su Iglesia desde la catedral hasta la parroquia del santo, donde se celebraba una solemne función religiosa. Además, era el propio regimiento, en la persona del caballero primiciero, quien custodiaba la llave de la reja que daba acceso a esas veneradas reliquias (Cabeza de Vaca, 1693: 84 y 98). En cuanto a los tres mencionados hijos del santo, se vivió precisamente un proceso de potenciación de su culto en las últimas décadas del siglo XVI y primeras del XVII, como sucedió con otras reliquias conservadas tanto en el monasterio de San Claudio, caso de las de San Ramiro y los doce monjes (Martín, 2019), como en la propia Iglesia catedral caso, por ejemplo, de las de San Pelayo. La recuperación de reliquias o la invención de los restos de supuestos mártires incrementaba no sólo el prestigio de la Iglesia y la ciudad sino también de sus propias elites. Así, los Rodríguez Lorenzana, aseguraban que San Vicente, abad de San Claudio martirizado por los arrianos, era integrante de su linaje, por lo que anualmente costeaban en dicho monasterio una función religiosa ${ }^{4}$.

De igual modo, la participación leonesa en la mítica batalla de Clavijo, con lo que suponía para el prestigio de la ciudad y sus principales linajes, se trató de hacer visible a través del ceremonial público. En este contexto, la fiesta de las cantaderas, que se desarrollaba el día de la Asunción de la Virgen, jugó un papel destacado. En ella, una serie de niñas engalanadas, en representación de las principales parroquias de la ciudad, danzaban en agradecimiento a la desaparición del tributo de las cien doncellas (Viforcos, 1994: 30-31). Aunque se desconoce el origen de esta celebración, lo cierto es que ni era tan antigua como los leoneses presumían ni tampoco tan original, existiendo algunas muy semejantes en territorios próximos, caso, por ejemplo, del Bierzo o Astorga. Sea como fuese, de lo que no hay duda es de su fuerte carga simbólica y propagandística que llevó incluso a ser empleada como prueba histórica en los pleitos del Voto de Santiago (Rey, 1994: 194).

Una ocasión propicia para poder transmitir en toda su plenitud aquella imagen mítica de la urbe era en el contexto de una visita regia. Sin embargo, tal circunstancia

4. AHN (Archivo Histórico Nacional), Estado-Carlos III, Exp. 93.

Ediciones Universidad de Salamanca / అ@@ Stud. his., H. ${ }^{a}$ mod., 41, n. 2 (2019), pp. 123-153 
se produjo en León muy excepcionalmente y cuando se desarrolló los resultados no fueron los deseados. A comienzos del siglo XVII Felipe III llegó a la ciudad junto a su esposa y un nutrido séquito, al objeto de tomar posesión del canonicato de la catedral de León que le correspondía «desde el tiempo de el gran rey Don Ramiro, que venció la insigne batalla de Clavijo» (Cabeza de Vaca, 1693: 117). Aquel solemne acto, desde luego, reforzaba el prestigio de la Iglesia legionense y de la propia ciudad, al legitimar su vinculación a la mítica victoria y reconocer el monarca con este y otros gestos - como la visita al panteón real de San Isidoro- (Cabrera, 1857: 130) su relación con la casa real leonesa.

Pero, aunque estos gestos regios fueron reflejados en obras posteriores, con evidente interés, y pese a que las fuentes oficiales del ayuntamiento tratan de dejar constancia en sus escritos de la magnificencia de las celebraciones desarrolladas durante aquella estancia regia (Cabeza de Vaca, 1693: 112), lo cierto es que la impresión que dejó la ciudad en el rey y sus allegados fue muy diferente. Lo que en la propaganda municipal fueron festejos llenos de lujo y colorido, a los ojos del monarca y sus nobles resultaron de una pobreza lamentable. Así lo señalaba el cronista cortesano Luis Cabrera de Córdoba, subrayando las dificultades del consistorio ya no sólo para preparar unas celebraciones acordes a la categoría de los visitantes, sino incluso a la hora de habilitar espacios adecuados para el descanso de los monarcas y el nutrido grupo de cortesanos que los acompañaban:

«Al otro día que era domingo hubo una máscara y torneo de caballeros de la ciudad, de poca costa, porque están muy pobres y necesitados, y se marcharon muchos a las aldeas para no tener que esperar a Su Magestad y no poder hacer regalos a los cortesanos; y así hubo muy poca gente en la ciudad, de lo que se informó a Su Magestad aquí antes que partiese, declarándole su pobreza y que no podían recibirle con la demostración que debían, lo cual él ha constatado por el frío y la falta de medios que ha sufrido» (Cabrera, 1857: 130).

Aquella modestia contrastaba con el orgullo desmedido que exhibieron los integrantes de las elites leonesas, lo que parece, dejó cierta impronta en los cortesanos, llegando a ser objeto de chanzas que, más tarde, tuvieron su reflejo en la famosa Pícara Justina. Su probable autor, el licenciado Francisco de Úbeda, formaba parte del círculo de servidores del poderoso D. Rodrigo Calderón, al que dedicó la obra (Ferreras, 2005: 15). Y hubiera o no asistido personalmente a la jornada regia, recogió en su libro aquellas impresiones, con críticas demoledoras llenas de innegable ingenio que puso en boca de su protagonista:

«No he visto hombres más moridos de amores por su pueblo, y es de manera que donde quiera que se halla un leonés, le parece que la mitad de la conversación en que se halla de debe de justicia a la corona y corónica de León. En esto, todos tienen 
una pega: paréceles a los leoneses que alabar otro pueblo y no a León es delicto contra la corona real» (López de Úbeda, 2005: 262).

Parece fácil entender que esos leoneses a los que se hace referencia eran aquellos integrantes de las elites que recibieron a la comitiva regia. Los mismos que iban sobrados en nobleza, vanagloriándose del pasado de su ciudad y de sus propios linajes, pero carentes del dinero suficiente como para ofrecer un recibimiento adecuado a los monarcas.

Estos contratiempos no impidieron que a lo largo del siglo XVII y hasta el último tercio del XVIII, las ideas defendidas por los autores de finales del Quinientos se mantuvieran a través del referido ceremonial público o incluso mediante nuevas obras impresas. Pues si bien es cierto que durante este período no vieron la luz en la imprenta libros de carácter histórico - al margen de los inéditos de Lázaro Díaz del Valle-, sí dejaron también su poso en otras que si bien no tenían como principal finalidad abordar estas cuestiones las trataban de soslayo. Por ejemplo, en sus Loores de los santos, el canónigo Gaspar Lozano y Regalado (1619) versificaba la vida o el martirio de los principales integrantes del santoral propio de la Iglesia legionense, aunque, a decir verdad, su importancia en el contexto de la obra es discreto. También es conocida por referencias una Vida de San Aristobolo Zebedeo primero obispo de León, escrita por un tal Antonio Díaz, al parecer clérigo, y publicada en la propia ciudad en 1670, que posiblemente trataba de entroncar la antigüedad de la Iglesia legionense con las tradiciones jacobeas (Bravo, 1902: 26).

En el propio Resumen de las políticas ceremonias del marqués de Fuentehoyuelo (Cabeza de Vaca, 1693) se hacían esporádicas referencias al pasado de la ciudad. O el dominico Fr. José Manzano, en la dedicatoria a Felipe V de sus Milagros de San Isidoro, hacía ver al monarca el alto honor que debía suponer para él «heredar sangre tan pura, tan catholica» como la de sus antecesores enterrados en el panteón regio de la colegiata (Manzano, 1732: dedicatoria). Además de realizar en su libro tercero, antes de narrar la historia del convento, un repaso al pasado histórico de la ciudad, tratando de su fundación romana, sus santos mártires, la conquista musulmana o su rápido rescate por Pelayo.

Fue el agustino Fr. Manuel Risco el último autor que trató en profundidad sobre las antigüedades de la ciudad de León y su Iglesia durante los siglos de la Edad Moderna, primero en los tomos correspondientes de la España Sagrada (XXXIV, XXXV y XXXVI), magna obra iniciada por el padre Flórez y continuada por aquel. Y después en dos más breves volúmenes que, a modo de resumen, fueron publicados con posterioridad. Obviamente, Risco no era Flórez y, en consecuencia, estas obras continuaban, en esencia, apoyando los postulados enarbolados por los autores de los siglos precedentes, obviando, cuando así era menester, la moderna crítica de fuentes que, teóricamente, se defendía en ellas. Esta actitud no extraña, al ser las elites leonesas las principales impulsoras de su labor. El propio Risco 
dedicaba los volúmenes de su España Sagrada a Francisco Antonio Lorenzana y Butrón, arzobispo de Toledo e integrante de uno de los más importantes linajes de la ciudad (Martín y Pérez, 2008). Otro destacado miembro de esa familia, Jacinto García de Herrera y Lorenzana, regidor perpetuo, caballero de la orden de Carlos III y a la sazón sobrino del arzobispo, fue el anfitrión del monje en su estancia leonesa, amén de proporcionarle los traslados de algunos documentos antiguos (Risco, 1784: prólogo).

Francisco Antonio Lorenzana, «zeloso de las glorias de su patria y de esta su nativa iglesia» ya había estado detrás de la actualización de la obra de Trujillo, encomendando un tiempo antes al canónigo y archivero Carlos Espinós del Pí su anotación crítica, de cara a una posible publicación que, como ya señalamos, no llegó a producirse (Trujillo, 1590: Prólogo, III). En una copia manuscrita conservada en la Biblioteca de Castilla-La Mancha, se añadió esta anotación marginal: «No se imprimió por ridiculez de la Academia de la Historia, cuya censura desagradó al Sr. Arzobispo, y porque después el P. Risco escribió la historia de la ciudad e Iglesia» ${ }^{5}$. Parece pues existir una clara vinculación entre el fracaso de la publicación del libro de Trujillo y el apoyo del arzobispo a la labor de Risco. Tal relación se vislumbra en el hecho, reconocido por el propio autor en el prólogo, de haber interrumpido la publicación de los volúmenes de las diócesis de la provincia tarraconense que había ya iniciado, para anteponer a la Iglesia de León, debido a «la autoridad y deseo de muchos, y la mayor utilidad que resultaba del reconocimiento de la Iglesia legionense por la gran multitud de sus instrumentos, junto con la facilidad que se me proporcionaba para su inspección» (Risco, 1784: prólogo). En consecuencia, si la propuesta de edición crítica del libro de Trujillo, respondiendo al claro objetivo de ensalzar la antigüedad y privilegio de la Iglesia legionense, se hacía desde unos postulados más moderados, la obra de Risco, en general, resulta mucho más beligerante y menos crítica en algunas de las cuestiones más complejas.

Ciertamente, el legado del catalán Carlos Espinós que fue canónigo de la Iglesia legionense entre 1741 y 1777 resultó de inestimable ayuda. Primero por la referida labor crítica del libro de Trujillo - dentro de los límites que permitía la defensa de su Iglesia-, de la que se aprovechó el historiador agustino, como ya puso de relevancia en su momento Juan Eloy Díaz-Jiménez (1889). Segundo, por su estimable trabajo de ordenación y conservación de los documentos antiguos custodiados en el archivo catedralicio, cuya consecuencia fue la elaboración de su cuidado manuscrito Serie Cronológica e histórica de las escrituras de la Santa Iglesia de León ${ }^{6}$, también conocido y empleado por Risco.

5. BCM (Biblioteca de Castilla-La Mancha), Manuscrito $n^{\circ} 20$.

6. BN, Manuscrito $n^{\circ} 9.139$. 
La dedicatoria de la España Sagrada, supone ya, de facto, una verdadera declaración de intenciones de la línea que va a seguir en esta obra y en las posteriores. En ella, siguiendo a Lobera y a Trujillo, se vuelve a hacer referencia a la antigüedad romana de León y a su papel en tiempos medievales como «soberano antemural y amparo de la christiandad de estos reinos y el glorioso principio de la prosperidad y salud pública», al liberar a otras ciudades del cautiverio musulmán, convirtiéndose de este modo en el origen de la Monarquía. También defiende la antigüedad de su Iglesia «cercana al tiempo de los apóstoles» (Risco, 1784: dedicatoria), en contra de lo afirmado categóricamente por el padre Flórez en el tomo IV de la España Sagrada, en donde, acertadamente, descartaba la existencia de un obispado anterior al período medieval (Flórez, 1749: 227-233). De hecho, seguramente fueron las contundentes afirmaciones de este ilustrado religioso las que generaron el posterior interés del arzobispo Lorenzana y de las elites leonesas por patrocinar la publicación de una obra reivindicativa que sirviese de contrapeso. Y, tras el fracasado intento de rescatar la obra de Trujillo, sin duda el padre Risco, como heredero de Flórez, era el autor más indicado para llevarla a cabo.

A pesar de que el agustino rechaza vehemente el influjo de los falsos cronicones y la sesgada información de algunas crónicas medievales, tachando por ejemplo la supuesta fundación de Lancia por Trimegisto de «juguete de la imaginación», a la hora de establecer los orígenes de la Iglesia legionense no tiene inconveniente en abrazar las suposiciones de Trujillo en cuanto a su existencia prácticamente desde los orígenes de la ciudad, antigüedad que se hace extensible, aunque con ciertos matices, a su privilegio de exención de los metropolitanos. De nuevo, tal evidencia se sustenta en sus mártires y en algunos documentos vagos y poco concluyentes. También rechaza la idea ya sugerida por Flórez y otros autores de la única existencia en tiempos de dominación sueva y visigoda de una sede en Astorga. Espinós, había tratado de salvar la cuestión aceptando en parte aquella tesis, convirtiendo a la sede asturicense en una continuadora de la legionense, al verse obligados los obispos de León, por los avatares políticos de la época, a residir en ella. Esta solución de compromiso fue descartada por Risco - por lo que podía generar de conflicto con los obispos astorganos - defendiendo la existencia de ambas sedes durante aquel período. Para tal fin, apoyándose en Lucas de Tuy, afirma que León, como principal guarnición militar de la Galicia romana, no había sido conquistada por los suevos, manteniéndose libre hasta la posterior conquista goda bajo Leovigildo (109). Este argumento no es baladí, ya que significaría que la Iglesia legionense se había mantenido en la ortodoxia sin influjo arriano ni en tiempo suevo ni prácticamente en el visigodo pues poco después de su conquista, Recaredo convirtió a su pueblo al catolicismo. Tal afirmación le lleva a tener que realizar auténticas piruetas para justificar el martirio del santo leonés Vicente y de sus compañeros monjes a manos de los arrianos. En cuanto a los santos mártires de la época romana, retoma la defensa de Facundo y Primitivo como anteriores a Marcelo, lo que venía a reforzar

Ediciones Universidad de Salamanca / అ@@ Stud. his., H. ${ }^{a}$ mod., 41, n. 2 (2019), pp. 123-153 
la antigüedad de la Iglesia legionense. De igual forma, hace una ardiente defensa del centurión como oriundo de León, aunque es más reservado en lo que concierne a su esposa y sus doce hijos, refiriéndose exclusivamente a Claudio, Lupercio y Victorico.

Finalmente, en lo que atañe al período medieval, remarca la importancia de la urbe como principal sostén de la lucha contra los musulmanes y la brevedad de su dominio sobre ella, si bien descarta la reconquista de la ciudad por Pelayo, responsabilizando de la misma a Alfonso I. Pasa de soslayo también por la problemática cuestión de la batalla de Clavijo y el tributo de las cien doncellas, aspecto que había gozado de mayor importancia en las obras precedentes, citándola solamente para justificar la canonjía de los monarcas y los marqueses de Astorga. En esta cuestión y en la del Voto de Santiago parece pues seguir la estela del padre Flórez (Rey,1985: 158), tratando de alejar la causa leonesa de una polémica que en nada podía beneficiarle, habida cuenta del cada vez más asentado escepticismo sobre tales cuestiones.

La obra de Risco tiene su prolongación en los dos libros publicados a posteriori a modo de una especie de resumen de la historia civil y eclesiástica de la ciudad, sobre la base de lo ya sustentado en la España Sagrada. Ambas, publicadas en 1792, gozaron del patrocinio del cabildo catedralicio y el concejo de León, visiblemente interesados por la difusión de las opiniones de tan benévolo defensor de los privilegios y excelencias de la ciudad. En su «Historia de la ciudad y corte de León» se hace un repaso de la evolución de la urbe y su reino, sin descuidar a sus reyes o la mención a sus principales linajes (Risco, 1792A). En la «Iglesia de León y monasterios antiguos y modernos de la misma ciudad» (Risco, 1792B), se vuelve a recalcar la antigüedad de su Iglesia, dejando caer la posible predicación de Santiago por aquellas tierras.

\section{EPÍLOGO: LA IMPRONTA DE LA PROPAGANDA MODERNA EN LOS SIGLOS POSTERIORES}

Con las obras del padre Risco se cierra el largo proceso de reivindicación de las glorias de la ciudad de León y su Iglesia durante la Edad Moderna. Sin embargo, no hay duda de que la notable producción impresa de aquellos siglos, unida a la propia proyección de los mensajes en ella defendidos a través del ceremonial público, calaron hondamente en la mentalidad colectiva, manteniéndose, con inevitables interferencias, durante la época Contemporánea. Aún en 1855, D. Pedro Alba, párroco de Voznuevo y prolífico autor de obras pretendidamente históricas, en su «Diseño de Geografía e Historia de la provincia y obispado de León», proseguía por el camino trazado por los cronistas de siglos atrás, llegando incluso en su ardiente defensa del arraigo del cristianismo en el territorio desde tiempos remotos, a sugerir la posibilidad de que los leoneses hubiesen llamado al propio Cristo para que les predicase, comprometiéndose éste a enviarles a un apóstol, como así se efectuaría con la figura de Santiago (Alba, 1855: 65). 
Ciertamente la obra de este clérigo responde más a las pautas de otros tiempos que a las nuevas perspectivas historiográficas imperantes tras la caída del Antiguo Régimen. De hecho, los autores del XIX renegaron de las viejas construcciones míticas sobre la fundación de la ciudad - calificadas como pueriles (Miñano, 1826: 199) o «errores inconcebibles» (Mingote, 1879: 85) -, rechazaron con vigor los hechos de Clavijo y el «apócrifo diploma del voto» (Madoz, 1983: 193) o desestimaron por completo las «fábulas propias de los tiempos heroicos» de Pedro de la Vecilla, en lo que se refería a las guerras sostenidas por los montañeses contra los romanos (García, 1867: 15). Tal postura crítica se conjugaba con una especial querencia por los tiempos medievales, en la que confluían los propios gustos del Romanticismo con las viejas premisas defendidas por los cronistas de los siglos antecedentes, que situaban a León como «no solo el baluarte de la monarquía cristiana, sino también su más ennoblecida corte» (García, 1867: 20). El innegable cariz político que conllevaba esa reivindicación del pasado medieval se constata de un modo harto evidente en un folleto dirigido en 1873 a las cortes constituyentes, en el contexto de la configuración de la república federal, donde entre otros argumentos se defendía la autonomía de la provincia en base a haber sido «cuna del primer reino de la Reconquista» (Bravo, 1902: 343). Esa vinculación entre el viejo reino y los postulados regionalistas o autonomistas tendrá un largo recorrido temporal, hallándose todavía viva en nuestros días y generando una inevitable mitificación de aquel pasado medieval, a veces personificado en héroes románticos, como Guzmán el bueno o Suero de Quiñones - por poner dos ejemplos significativos (Mingote, 1880) - o, a veces, en determinados acontecimientos puestos en tela de juicio por la historiografía actual, caso de las supuestas cortes de 1188 (Estepa, 1988).

Estas ideas mitificadoras se condensan de un modo harto ilustrativo en el famoso «Himno a León», compuesto en la década de los treinta del siglo XX por José Pinto Maestro y musicado por Odón Alonso. Las alusiones al pasado recogidas en él beben directamente de aquella octava real con la que comenzábamos este trabajo o de las ya analizadas obras de los siglos XVI al XVIII y responden, en gran medida, a la referida preponderancia del pasado medieval como legitimador de la esencia leonesa y de su importante contribución a la creación de España:

\author{
Sin León no hubiera España, \\ que antes que Castilla leyes, \\ concilios, fueros y reyes \\ dieron prestigio a León. \\ La fama cantó su hazaña \\ con clarines de victoria. \\ León escribió la historia \\ de Covadonga a Colón.
}


Junto al pasado medieval, el segundo soporte que prestigiaba a León, en atención al texto del himno, era el peso del cristianismo, siguiendo pues en este sentido también la estela de los escritores de la Edad Moderna. En su segunda estrofa se le define como «de santidad osario/ del arte relicario/ y de la fe expresión.». Y es que, si los autores decimonónicos fueron en gran medida beligerantes en lo que respecta a los orígenes míticos de la ciudad, evidenciaron una mayor credulidad a la hora de abordar la cuestión de la antigüedad de su Iglesia. Si en el Miñano se pasaba de puntillas sobre esa cuestión, el corresponsal de Pascual Madoz no tuvo inconveniente en seguir, en esencia, las tesis de Risco, realzando la importancia de su santoral «lo que hace sobresalir maravillosamente a León entre las demás ciudades del reino cristiano» (Madoz, 1983: 197). Línea continuada unos años más tarde por José García de la Hoz o Policarpo Mingote quienes, como los autores de antaño, se apoyaron en los mártires Emeterio, Celedonio, Marcelo y sus hijos para sostener el arraigo del cristianismo en tierras leonesas y la antigüedad de las diócesis legionense y asturicense (García, 1867: 17; Mingote, 1879, 89; Mingote, 1880: 5-6). A este respecto, sin duda, fue el episcopologio de Juan de Dios Posadilla, cuyo seguidismo de la obra de Risco está fuera de toda duda (Bravo, 1902: 467), el que de un modo más extenso defendió tal antigüedad, apoyándose en las manidas argumentaciones del monje y los cronistas precedentes (Posadilla, 1899: X-XXI).

Sin embargo, si el aporte medieval ha mantenido su vigencia durante el siglo $\mathrm{XX}$ hasta nuestros días como elemento legitimador del hecho diferencial leonés, los argumentos de carácter religioso han ido perdiendo calado paulatinamente en el contexto del proceso de secularización de la sociedad, en especial tras la llegada de la democracia. Esa tendencia, no obstante, no ha impedido que en tiempos recientes hallamos asistido perplejos a la irrupción de algún nuevo episodio de inventio de reliquias, más imaginativo incluso que los estudiados para la época moderna o medieval y que, a pesar de su evidente anacronismo, ha gozado de cierto eco mediático, merced a la preocupante importancia en nuestros tiempos de las pseudociencias y la literatura de lo mistérico (Henriet, 2015: 20-21).

\section{BIBLIOGRAFÍA}

ALBA, P. (1855). Diseño de Geografía e Historia de la provincia y obispado de León. León: Imprenta de la viuda e hijos de Miñón.

ÁLVAREZ, C. (1992). La ciudad de León en la Baja Edad Media. León: Sociedad Anónima Hullera Vasco-Leonesa.

ARANDA PÉREZ, F.J. (2001). Autobiografías ciudadanas. Historias, mitomanía y falsificación en el mundo urbano hispánico de la Edad Moderna. En E. García (ed.). El poder en Europa y América: mitos, tópicos y realidades. Zarautz: Universidad del País Vasco, 141-168. 


\section{ALFREDO MARTÍN GARCÍA \\ SIN LEÓN NO HUBIERA ESPAÑA. HISTORIA, RELIGIÓN Y PROPAGANDA EN UNA CIUDAD DE LA EDAD MODERNA}

BANGO TORVISO, I. (2004). Catedral de León. Desde la instauración de la diócesis hasta la magna obra de Manrique de Lara. En Yarza Luaces, J., Herráez Ortega, M.V. y Boto Varela, G. (coords.), La Catedral de León en la Edad Media. León: Universidad de León, 45-57.

BRAVO GUARIDA, C. (1902). La imprenta en León (apuntes para una monografía). León: Imprenta de Maximino A. Miñón.

CABEZA DE VACA, F. (1693). Resumen de las políticas ceremonias con que se govierna la noble, leal y antigua ciudad de León, cabeza de su reyno. Valladolid: En la imprenta de Valdivieso.

CAMPOS SÁNCHEZ-BORDONA, M.D. y VIFORCOS MARINAS, M.I. (1995). Honras fúnebres reales en el León del Antiguo Régimen. León: Universidad de León.

CAMPOS SÁNCHEZ-BORDONA, M.D. (2006). El culto a las reliquias en la provincia de León. En F. Rodríguez (ed.). La iglesia local: hogar de comunión y misión. Salamanca: Universidad Pontificia de Salamanca, 215-225.

CONCEPCIÓN, Fr. J. de la (1690). Emporio de el orbe, Cádiz ilustrada : investigacion de sus antiguas grandezas, discurrida en concurso de el general imperio de España. Ámsterdam: en la imprenta donde tiene la administracion Joan Bus.

CUART MONER, B. (2011). Una mentira hermosa y aparente por su antigüedad. Héroes, fundadores, ciudades y libros de Historia. En S. Truchuelo, R. López y M. Torres (eds.). Civitas: expresiones de la ciudad en la Edad Moderna. Santander: Universidad de Cantabria, 53-72.

DÍAZ-JIMÉNEZ Y MOLLEDA, J.E. (1889). I. Archivo de la Santa Iglesia Catedral de León. D. Carlos Espinós del Pí. Boletín de la Real Academia de la Historia. T. XIV, cuaderno V. 369-379. Consulta en red: http://www.cervantesvirtual.com/obra-visor/ boletin-de-la-real-academia-de-la-historia--33/html/025e6a60-82b2-11 df-acc7002185ce6064_114.html\#I_97_(consultado el 20/06/2019).

DÍAZ-JIMÉNEZ Y MOLLEDA, J.E. (1925). Jovellanos en León. Madrid: Tip. de la «Rev. de archivos, bibliotecas y museos».

ESCOBAR GARCÍA, F. (1963). Un libro y un poema olvidados. Tierras de León: Revista de la Diputación Provincial. Vol. 3, 4, 43-60.

ESTEPA DÍEZ, C. (1977). Estructura social de la ciudad de León (siglos XI-XIII). León: Centro de Estudios e Investigación «San Isidoro».

ESTEPA DÍEZ, C. (1988). Curia y cortes en el Reino de León. En Las Cortes de Castilla y León en la Edad Media. Valladolid: Cortes de Castilla y León, Vol. I, 23-103.

FARMHOUSE ALBERTO, P. (2011). Poesía en el reino de León: Los himnos en honor de San Facundo y San Primitivo. En P. Farmhouse y R. Furtado (coords.). Cuando Portugal era reino de León. Estudios sobre cultura e identidades antes de D. Alfonso Enríquez. León: Universidad de León, 201-212.

FERNÁNDEZ FLÓREZ, M. C. (2003). Aportes a la épica culta del siglo XVI: El León de España, de Pedro de La Vecilla Castellanos, un gran desconocido. En C. Castillo y J. M. Lucía (eds.), Decíamos ayer... Estudios de alumnos en honor a María Cruz García de Enterría. Alcalá de Henares: Universidad de Alcalá, 173-188.

Ediciones Universidad de Salamanca / అ@@ Stud. his., H. ${ }^{a}$ mod., 41, n. 2 (2019), pp. 123-153 
FERRERAS TASCÓN, J.I. (2005). Estudio preliminar de la Pícara Justina. En Úbeda, F. de, Libro de entretenimiento de la Pícara Justina. León: Lobo Sapiens (notas y transcripción de Rey Hazas, A.), 11-59.

FLÓREZ, E. (1749). España Sagrada: Theatro geographico-historico de la Iglesia de España: Tomo IV. Y el ultimo de la Iglesia en comun. Madrid: Por Antonio Marín.

HENRIET, P. (2015). Le Graal est à León!. L'Historie. 412, 20-21.

GARCÍA DE LA HOZ, J. (1867). Crónica de la provincia de León. Madrid: Rubio y Compañía.

GARCÍA MARCOS, V. (2004). Los campamentos de las legiones VI Victrix y VII Gemina en León. En C. Pérez y E. Illaregui (coords.), Arqueología Militar romana en Europa. Salamanca: Junta de Castilla y León/SEK, 197-198.

GARCÍA RODRÍGUEZ, C. (1966). El culto de los santos en la España romana y visigoda. Madrid: CSIC.

GARIBAY Y ZAMALLOA, E. de (1571). Los XI libros d'el compendio historial de las chronicas y vninersal historia de todos los reynos de España. Amberes: por Christophoro Plantino (3 vols.).

GONZÁLEZ ALONSO, E. (1997). Lancia. Fuentes e historiografía. Lancia. Revista de Prebistoria, Arqueología e Historia Antigua del Noroeste Peninsular, 2, 181-206.

GONZÁLEZ BLANCO, A. (1998). Bibliografía sobre los santos mártires calagurritanos Emeterio y Celedonio. Kalakoricos, 3, 271-280.

GONZÁLEZ BLANCO, A. (2000). Bibliografía sobre los santos mártires calagurritanos Emeterio y Celedonio (II). Kalakoricos, 5, 371-390.

GONZÁLEZ LOPO, D. (2005). Froilán de Lugo. Biografía e culto dun home santo (Ensaio de revisión haxiográfica). Lugo: Concello de Lugo.

KAGAN, R.L. (1995). La corografía en la Castilla Moderna. Género, Historia, Nación. Studia Historica. Historia Moderna, 13, 47-59.

LOBERA, A. de (1596). Historia de las grandezas de la muy antigua y insigne ciudad, y Iglesia de Leo[n] y de su Obispo y Patron Sant Froylan, con las del glorioso S. Atilano obispo de Çamora, Valladolid: por Diego Fernandez de Cordoua.

LÓPEZ DE ÚBEDA, Francisco (2005). Libro de entretenimiento de la Pícara Justina. Alicante: Biblioteca Virtual Miguel de Cervantes. (1ª . Ed. Medina del Campo, 1605) (En línea) http://www.cervantesvirtual.com/obra/libro-de-entretenimiento-de-lapicara-justina--0/ (Consultado el 12/06/2019).

LOZANO Y REGALADO, G. (1619). Loores de los santos de quien reza y haze conmemoración la Yglesia de Roma y las de España con los santos que en particular celebra la de León, por los meses del año. Valladolid: por Juan de Rueda.

MADOZ, P. (1983). Diccionario geográfico-estadístico-bistórico de España y sus posesiones de Ultramar por Pascual Madoz. Castilla-León. Valladolid: Ámbito.

MANSILLA REOYO, D. (1980). Obispados exentos de la iglesia española. Hispania Sacra, XXXII, 65/66, 287-321.

MANZANO, J. (1732). Vida y portentosos milagros del glorioso San Isidro, arzobispo de Sevilla y egregio doctor y maestro de las Españas, con una breve descripción de su

Ediciones Universidad de Salamanca / 요 Stud. his., H. ${ }^{a}$ mod., 41, n. 2 (2019), pp. 123-153 
ALFREDO MARTÍN GARCÍA

SIN LEÓN NO HUBIERA ESPAÑA. HISTORIA, RELIGIÓN Y PROPAGANDA

EN UNA CIUDAD DE LA EDAD MODERNA

magnifico Templo y Real Casa de el mismo señor San Isidro en la muy Noble Ciudad de León. Salamanca: en la Imprenta real.

MARIANA, J. de (1780). Historia general de España. Madrid: por D. Joaquín de Ibarra, impresor de cámara de Su Magestad ( $1^{a}$ ed. en castellano 1601), Tomo I.

MARTÍN GARCÍA, A. y PÉREZ ÁLVAREZ, M.J. (2008). Estrategias de reproducción social de la elite de la ciudad de León en la Edad Moderna. Nuevo Mundo Mundos Nuevos. (En línea) http://journals.openedition.org/nuevomundo/20502 (consultado el 15/06/2019).

MARTÍN GARCÍA, A. (2019). Religiosidad local en el León de la Edad Moderna: el hallazgo y culto de las reliquias del monasterio de San Claudio. Studia Monastica, 61, 47-70.

MARTÍNEZ GARCÍA, F. (1982). Historia de la literatura leonesa. León: Everest.

MARTÍNEZ LÓPEZ, M.E. (2017). Religiosidad e identidad urbana en la ciudad de León desde 1230. En G. Cavero (coord.). Construir la memoria de la cindad: espacios, poderes e identidades (XII-XV). León: Universidad de León, 349-437.

MARTÍNEZ PEÑÍN, R. (2011). Análisis de la producción y distribución de la cerámica leonesa durante la Edad Media. Oxford: Aarchaeopress (B.A.R.).

MARTÍNEZ PEÑÍN, R. (2019). El monasterio de San Claudio de León en la Edad Media. Estudio arqueológico y documental. Studia Monastica, 61, 27-46.

MASDEU, J. F. (1783-1805). Historia crítica de España y de la cultura española. Madrid: por Don Antonio de Sancha, Tomo XIX (1800).

MELITON MEMIGE, F. (1798). Historia de los santos mártires Servando y Germán, patronos de Cádiz. Cádiz: impresa por D. Manuel Ximenez Carreño.

MINGOTE Y TARAZONA, P. (1879). Guía del viajero en León y su provincia. León: Establecimiento tipográfico de Miñón.

MINGOTE Y TARAZONA, P. (1880). Varones ilustres de la provincia de León. León: Establecimiento tipográfico de Miñón.

MIÑANO, S. de (1826). Diccionario geográfico-estadístico de España y Portugal. Madrid: Imprenta de Pierart-Peralta, Tomo V.

MORALA RODRÍGUEZ, J. R. e IGLESIAS BANGO, M. (1999). El León de España, de 1586, y la norma culta ante los reajustes de los siglos XVI-XVII. En J.E. Martínez (coord.). Trilcedumbre. Homenaje al profesor Francisco Martínez García. León: Universidad de León, 351-360.

MORALES, A. de (1765). Viage de Ambrosio de Morales por orden del rey D. Phelipe II a los reinos de León, Galicia y principado de Asturias para reconocer las reliquias de santos, sepulcros reales y libros manuscritos de cathedrales y monasterios. Madrid: Por Antonio Martín.

MORGADO GARCÍA, A. (2009). La Historia local en el área gaditana en la Edad Moderna. En J.J. Bravo y S. Villas (eds.). Tradición versus innovación en la España Moderna. IX Reunión Cientifica de la Fundación Española de Historia Moderna. Málaga: Universidad de Málaga, 945-960.

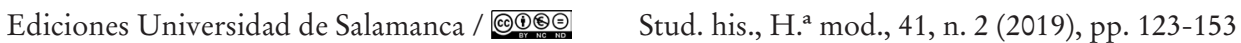


ALFREDO MARTÍN GARCÍA

SIN LEÓN NO HUBIERA ESPAÑA. HISTORIA, RELIGIÓN Y PROPAGANDA EN UNA CIUDAD DE LA EDAD MODERNA

MUÑOZ Y ROMERO, T. (1858). Diccionario bibliográfico-bistórico de los antiguos reinos, provincias, ciudades, villas, iglesias y santuarios de España. Madrid: Imprenta de Ribadeneira.

ORELLA UNZUÉ, J. L. (1999). Geografías guipuzcoanas de la modernidad (4): Baltasar de Echave y Lope Martínez de Isasti. Lurralde. Investigación y espacio. 22, 247-278. (En línea) http://www.ingeba.org/lurralde/lurranet/lur22/ore22/22ore.htm (consultado el 18/06/2019).

PEREDA F. y MARÍAS F. (2004). De la cartografía a la corografía. Pedro Texeira en la España del Seiscientos. Ería: Revista cuatrimestral de geografía. 64-65, 129-157.

PÉREZ ÁLVAREZ, M.J. y MARTÍN GARCÍA, A. (2009). Elites, poder local y redes familiares en la ciudad de León durante el siglo XVII. En E. Soria, J.J. Bravo y J.M. Delgado (coords.). Las élites en la época moderna: la monarquía española. Córdoba: Universidad de Córdoba, Vol. 2 (Familia y redes sociales), 313-324.

PÉREZ-EMBID WAMBA, J. (2002). Hagiología y sociedad en la España Medieval. Castilla y León (siglos XI-XIII). Huelva: Universidad de Huelva.

POSADILLA, J.D. (1899). Episcopologio legionense. León: Imprenta de Maximino A. Miñón. Tomos I y II.

QUESADA, S. (1992). La idea de ciudad en la cultura hispana de la Edad Moderna. Barcelona: Universitat de Barcelona.

RABAEY, H. (2010). Aclaraciones biográficas en torno al humanista leonés Antonio de Obregón. Minerva, 23, 251-259.

REGLERO DE LA FUENTE, C. (2016). La diócesis de León en la Edad Media. En Fernández, F.J. (coord.), Historia de las diócesis españolas. 17. Oviedo, León. Madrid: Biblioteca de Autores Cristianos, 575-652.

REY CASTELAO, O. (1985). La historiografía del Voto de Santiago. Santiago de Compostela: Universidad de Santiago de Compostela.

REY CASTELAO, O. (1994). Historia e imaginación: la fiesta ficticia. Semata. Ciencias Sociais e Humanidades, 6, 185-196.

REY CASTELAO, O. (2003). Libros y lectura en Galicia. Siglos XVI-XIX. Santiago de Compostela: Xunta de Galicia.

REY CASTELAO (2015). Las ciudades sin historia o la cronística pobre del noroeste castellano, 1580-1650. En Truchuelo, S., López, R. y Torres, M. (eds.). Civitas. Expresiones de la ciudad en la Edad Moderna. Santander: Universidad de Cantabria, 53-72.

RIBADENEIRA, P. de (1716). Flos sanctorum. Quinta parte. En la que se contienen la vida de los santos que pertenecen a los meses de setiembre y octubre. Madrid: en la imprenta de Agustin Fernandez.

RISCO, M. (1784). España Sagrada. Tomo XXXIV. Contiene el estado antiguo de de la Santa Iglesia esenta de León. Con varios documentos y escrituras concernientes a los puntos que en él se tratan: sacadas en la mayor parte de su Archivo. Madrid: en la oficina de Don Blas Román.

RISCO, M. (1786). España Sagrada. Tomo XXXV. Concernientes a los siglos XI, XII y $X I I I$, fundadas en escrituras y documentos originales, desconocidos en la mayor parte

Ediciones Universidad de Salamanca / 요 Stud. his., H. ${ }^{a}$ mod., 41, n. 2 (2019), pp. 123-153 
hasta abora y muy utiles para la Historia de esta ciudad, del Reyno de Leon, y de la España en general. Madrid: en la oficina de Don Blas Román.

RISCO, M. (1787). España Sagrada. Tomo XXXVI. Memorias de la Santa Iglesia esenta de León, concernientes a los cinco últimos siglos, con un copioso apéndice de concilios, escrituras y otros documentos muy útiles para la Historia particular de esta Cindad y su Iglesia y para la general del Reyno. Madrid: en la oficina de Don Blas Román.

RISCO, M. (1792A). Historia de la ciudad y corte de León y de sus reyes, iglesia y monasterios antiguos y modernos. Madrid: en la oficina de Don Blas Román.

RISCO, M. (1792B). Iglesia de León y monasterios antiguos y modernos de la misma ciudad. Madrid: en la oficina de Don Blas Román.

RUBIO PÉREZ, L.M. (1992). León 1751. Según las Respuestas Generales del Catastro de Ensenada. Madrid: Tabapress.

TRUJILLO, F. (1590). Historia de la Santa Iglesia de León. Manuscrito.

VECILlA CASTELLANOS, P. de la (1586). Primera y segonda parte de El Leon de España. Salamanca: en casa de Juan Fernández.

VIFORCOS MARINAS, I. (1992). El León barroco: los regocijos taurinos. León: Universidad de León.

VIFORCOS MARINAS, I. (1994). La Asunción y el Corpus. De Fiestas Señeras a Fiestas Olvidadas. León: Universidad de León.

VILÀ, L. (2007). Los poemas de la «fundación nacional». La épica del siglo XVII y la idea del imperio. Conceptos. Revista de Investigación Graciana, 4, 53-67.

VILLEGAS, Alonso de (1585). Flos sanctorum. Historia general de la vida y bechos de Christo, Dios y Señor nuestro, y de todos los sanctos de que reza y haze fiesta la Iglesia Catholica conforme al Breviario Romano, reformado junto con la vida de los sanctos propios de España, de otros extravagantes. Quitadas algunas cosas apocriphas $e$ inciertas. $Y$ añadidas muchas figuras y autoridades de la Sagrada Escriptura traydas a propósito de las Historias de los sanctos. Zaragoza: en casa de Simon de Portonariis.

Ediciones Universidad de Salamanca / @@ Stud. his., H. ${ }^{a}$ mod., 41, n. 2 (2019), pp. 123-153 